\title{
The science of politics
}

\section{Jacqueline Reynolds}

Science and the Founding Fathers. By I. Bernard Cohen. Norton: 1995. Pp. 368. \$25, £17.95.

THE hallmark of the eighteenth century, $l e$ siècle des lumières, was revolution - revolution of human thought as well as actual insurrection against established governments. This was the age in which old dogma passed away, reason was held to be supreme, science flourished in the salon as well as the laboratory. Newtonian principles and Lockian philosophy were as much a part of the scene as were the fine arts. At the same time and amid much bloodshed, France brutally deposed a hated monarchy, and British subjects in the New World ousted the troops of George III, founding a new republic. Among the principal players in these political and martial events were renowned intellectuals of the day.

In Science and the Founding Fathers, I. Bernard Cohen examines the role that science played in shaping the political thought of some of these eighteenth-century Americans - principally, Thomas Jefferson, Benjamin Franklin, John Adams and James Madison. Not surprisingly, we find much of their writing and political rhetoric sprinkled with scientific analogies and metaphors. References to science, whether direct or indirect, gave an authoritative ring to political argument and appealed to the popular desire to place all areas of human endeavour in the realm of reason and rationality. Perhaps of more interest is the fact that the repeated use of scientific metaphor by politicians implies a familiarity on the part of the audience with the details and nuances of the science of the day, a situation very different from the near scientific illiteracy of our own age. Can one imagine a modern prime minister or president using Newton's Principia as a basis for political analogy? For that matter, can one imagine a modern prime minister or president even reading the Principia?

Cohen devotes separate chapters to Jefferson, Franklin and Adams and a final section to "Science and the Constitution". We are introduced to Jefferson as a polymath actively involved in agriculture, mathematics, physics, astronomy, natural history, palaeontology and archaeology. The author takes us through Franklin's principal contributions to the science of electricity and Adams's somewhat confused ideas about Newtonian mechanics. But the main thrust of the book is to connect these scientific activities with the more public part of their lives, to show "that the history of science can illuminate some of the central aspects of American history".

A few examples should suffice to provide the flavour of Cohen's thesis. Thus Jefferson, the architect of the Declaration of Independence, used the phrase "the laws of nature and nature's God" words that were common parlance in the

a problem that seems to recur in the writings of some historians and biographers. Cohen is at such pains to correct this misunderstanding of the contents of the Principia that he dwells at length on this topic in eight different sections of his book - a slightly irritating and unnecessary repetition.

A further example of the influence of science in the newly formed United States is found in the political and public life of Franklin. His principal role for many years was in representing his country and his country's interests abroad where his influence came not only from the force of his personality (com-

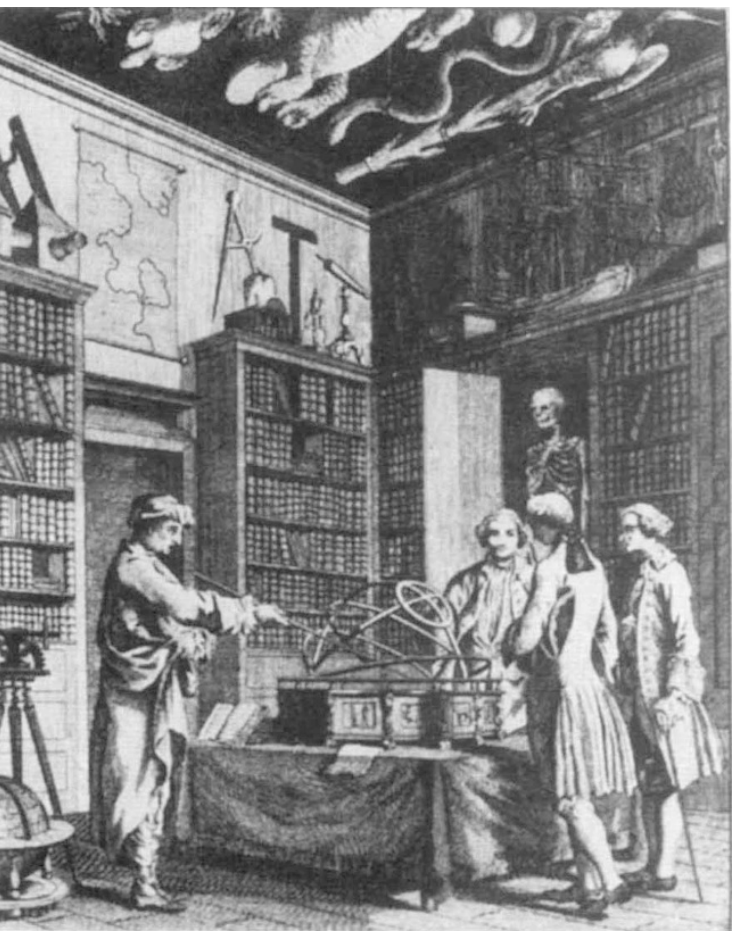

This print, published in 1760 a year before Jefferson ntered the College of William and Mary, Williamsburg, as freshman, shows the master of natural philosophy monstrating the features of the orrery.

eighteenth century and held a special scientific significance. Primarily, this was a Cartesian expression that was universally adopted for the fundamental principles of science, and its use reflects both Jefferson's own background and its association in the minds of men of learning with Newtonian axioms.

Similarly, Adams invoked the physical concepts of balance and equilibrium in support of his strong views on the necessity for checks and balances within the structure of government. Cohen comments on Adams's Defence of the Constitutions of Government of the United States of America: "one is sometimes hard put to discern whether he is writing about politics and social issues or about the science of statics". But Adams did not have the grasp of Newtonian physics of some of his contemporaries and not infrequently confused the principles of mechanical dynamics with those of static equilibrium, mon sense and general good will) but also from the esteem in which he was held for his scientific accomplishments.

Finally, we come to consider that most important of political documents, the Constitution of the United States of America, drafted by James Madison and his fellow E representatives to the Constitutional Convention. (Note that Jefferson and Adams were not a part of this group, and that Franklin, who was present, argued unsuccessfully for a unicameral legislature.) Some American historians and political scientists have postulated that this document is Newtonian in origin, an interpretation roundly rejected by Cohen and apparently attributable in the first instance to Woodrow Wilson another of our characters who misunderstood the thrust of Newtonian mechanics.

Science and the Founding Fathers ends with a collection of 12 short essays (in the modern sense) covering an extraordinary range of subjects, for example "The meaning of science and experiment", "Jefferson and the Megalonyx or Megatherium" and "Adams' speculations about respiration and magnetism". These supplements enlarge upon themes elsewhere in the book but could well stand alone, a brief testimony to the interweaving of eighteenth-century science with the fabric of political life.

Cohen is a respected historian, noted especially for his studies of the works of Franklin and Newton, and is well placed to judge the influence of scientific thought on early American political life. Historians and scientists should find this book rewarding, a reminder of the days when science and society marched hand in hand. It might even enlighten a few politicians if they could be persuaded to read it

Jacqueline Reynolds, emeritus professor at Duke University, is at Tarlswood, Back Lane, Easingwold, North Yorkshire Y06 3B6, UK. 